\title{
Knowledge, attitude and practices of healthcare workers regarding biomedical waste segregation at Mayo Hospital Lahore.
}

\footnotetext{
1. MBBS

House Officer Medicine

Mayo Hospital, Lahore.

2. MBBS, MPH, MA (Social Work)

Assistant Professor Community

Medicine

King Edward Medical University,

Lahore, Pakistan.

3. MBBS

House Officer Surgery

Mayo Hospital, Lahore.

4. MSc (Statistics), M.Phil, Ph.D

Assistant Professor Statistics

The Women University Multan,

Pakistan

5. MBBS, M.Phil

Assistant Professor Pathology King Edward Medical University, Lahore, Pakistan.
}

Correspondence Address:

Dr. Saleha Qasim

Mayo Hospital, Lahore.

salehaqasim96@gmail.com

Article received on:

06/07/2019

Accepted for publication:

$26 / 02 / 2020$

\begin{abstract}
Saleha Qasim¹, Ainul Momina², Fatima Tul Zahra ${ }^{3}$, Tahira Bano Qasim4, Fakeha Rehman ${ }^{5}$
\end{abstract}
ABSTRACT... Objectives: This study has been designed to assess the knowledge, attitude and practices of healthcare workers at Mayo Hospital regarding biomedical waste segregation. Study Design: Cross-sectional study. Setting: Teaching Hospital of King Edward Medical University Lahore, Pakistan. Period: February 2018 to January 2019. Material \& Methods: Structured questionnaires in English and Urdu were employed to collect data from healthcare workers (nurses and doctors) on duty in different wards of Mayo Hospital. The demographics, level of knowledge, practices and attitude regarding biomedical waste segregation are reported using descriptive statistics. The comparison of doctors and nurses is done using chisquare. Results: Significantly fewer number of doctors correctly identified the container for bio hazardous waste $(p=0.016)$, while majority $(89.4 \%)$ of respondents were able to correctly identify the container for sharps and general waste. Significantly more $(p=0.00)$ number of nurses had training in waste segregation as compared with doctors. Majority (95.0\%) of nurses acknowledged that guidelines regarding waste segregation were available in their departments, whereas significantly lesser number $(64.5 \%)$ of doctors acknowledged existence of guidelines at their workplace $(p=0.00) .21 .3 \%$ of respondents claimed to have acquired infection from waste with no statistical difference between the two groups $(p=0.19)$. A minority of the participants agreed that the practices were satisfactory $(14.6 \%)$ and the required equipment was available $(27.7 \%)$, yet there was a significant difference between the responses of doctors and nurses with the nurses being more satisfied with the available facilities and equipment $(p=0.00)$ than doctors. Conclusion: The knowledge of the healthcare workers regarding waste segregation is better than their practices, nonetheless there is a dire need to improve the quality of training of these health care workers in and emphases must be put on ensuring that correct practices are adopted.

Key words: Biohazards, Waste Management, Waste Segregation.

Article Citation: Qasim S, Momina A, Fatima Tul Zahra, Qasim TB, Rehman F. Knowledge, attitude and practices of healthcare workers regarding biomedical waste segregation at Mayo Hospital Lahore. Professional Med J 2020; 27(12):2755-2762. https://doi.org/10.29309/TPMJ/2020.27.12.3888

\section{INTRODUCTION}

Biomedical waste $[B M W]$ is defined as "any solid, fluid or liquid waste, including its container and any intermediate product, which is generated during the diagnosis, treatment or immunization of human beings or animals, in research pertaining thereto, or in the, production or testing of biological and the animal wastes from slaughter houses or any other like establishments."1 According to World Health Organization, about $85 \%$ of the waste generated during health-care related activities is general, non-hazardous waste similar to domestic waste. The other $15 \%$ is comprised of hazardous matter that can be infectious, radioactive or chemical. ${ }^{2}$
The segregation of this waste is a foremost step of biomedical waste management which reduces the quantity of hazardous waste requiring special treatments. Biomedical waste management is a crucial element of health system and the respective institutes. Its improper management can lead to serious health dilemmas which can affect the general public and the health care personnel through spread of contagious diseases and radioactive material.

The important hazards emphasized by WHO include drug-resistant microbes which transmit from health centres into the environment, sharp 
inflicted injuries, exposure to toxic pharmaceutical products, air pollution, thermal, radiation and chemical burns. ${ }^{2}$ Furthermore, the persons in contact with the waste directly or indirectly are at risk of acquiring these hazards. ${ }^{3}$ Hence, protective protocols and the use of personal protective instruments must be established and ensured. Serious infections are being transmitted to the susceptible individuals through medical waste. A meta-analysis based on a systemic review displayed a positive relation between exposure to domestic or healthcare waste and presence of markers for HBV infections in the blood i.e. $\mathrm{HBsAg}$ and anti-HBc [odds ratio (OR) being 1.89, with confidence interval $(\mathrm{Cl})$ of $95 \%, 1.27-2.86$; p-value $=0.0019]$. $^{4}$

In accordance with the seriousness of the issue, detailed guidelines have been formulated by the World Health Organization (WHO) and The International Solid Waste Association related to the segregation and overall management of health-care related waste. ${ }^{5}$ The amount of waste produced varies with the type of health facilities, health care departments and among the countries. HCWGRs are commonly lower for developing and low income countries compared with the high income countries or developed world. ${ }^{6,7}$ In Greece, the mean Hazardous Medical Waste Unit Generation Rate was found to vary from $0.012 \mathrm{~kg} /$ bed/day, in the public sector psychiatric hospitals, to approximately $0.72 \mathrm{~kg} / \mathrm{bed} / \mathrm{day}$, in the public sector university hospitals. ${ }^{8}$

Based on these variations and the available resources, every country has formulated specified local guidelines for Biomedical Waste Management. ${ }^{9}$ To reduce the cost, segregation of hazardous from the non-hazardous waste holds special importance as it reduces the bulk of hazardous waste. This practice relies on the knowledge and practices of health care workers regarding medical waste segregation. A study in Trivandrum, India has shown that doctors and nurses had superior knowledge about hospital waste management as compared to ward cleaners but no significant difference was found in their attitude. ${ }^{10}$ Similar studies have shown poor practices of hospital waste management in various centers. ${ }^{1,11,12}$ As a result of this poor knowledge and practices regarding waste segregation, the total amount of hazardous waste increases in amount. According to WHO guidelines it is required that every medical personnel must have adequate knowledge, attitude and practice about medical waste management. ${ }^{13}$

In Pakistan, Health Waste Management Rules were formulated in 2005. ${ }^{14}$ These were restated and an Environmental and Medical Waste Management Plan was devised by the Govt. of Punjab as a component of Punjab Health Sector Reforms Support Project in January 2013.15 A study assessing the waste management status in the hospitals of Islamabad and Rawalpindi has shown that majority of the hospitals did not prioritized the practice of HCWM. Segregation, storage, handling, disposal and transportation of waste were not up to WHO or Pakistan biosafety rules 2005 standards. ${ }^{11}$ In a similar study, the level of knowledge in doctors and nurses as compared with paramedics and sanitary staff was assessed and this was significantly related to demographics, level of education and experience of the respondents. ${ }^{16}$

Although a lot of studies have been done on this issue in different countries of the world, significant amount of data is lacking from Pakistan. Hence, this study has been designed to assess the knowledge, attitude and practices of health care workers regarding biomedical waste segregation at Mayo Hospital Lahore. In the current settings, the segregation is done at the bedside and ward level by the attending nurses and junior doctors (mostly House Officers) who deal with the waste directly. Hence this study targets the healthcare workers (nurses and doctors) who are more concerned with waste segregation and bedside care of patients. The study is aimed at assessing the knowledge, attitude and practices of health care workers regarding medical waste segregation at Mayo Hospital Lahore.

\section{MATERIAL \& METHODS}

A cross-sectional study was designed at Mayo Hospital Lahore; the teaching hospital attached to King Edward Medical University, the oldest and one of the most prestigious medical institutes of 
the country. The ethical approval for conducting the study was obtained from the institutional review board (IRB) of King Edward Medical University (Letter No. 245/RC/KEMU). A sample size of 120 health care workers was estimated by using 95\% confidence level, 9\% absolute precision with expected percentage of HCWs well aware of Health Care Waste Segregation to be $48 \%$.

Participants were included using non probability convenience sampling. The authors of the study visited the wards at various times and the nurses and doctors at bedside were requested to fill a self-administered structured questionnaire designed specifically for this study after modifying the questions of similar studies. The questionnaire was originally designed in English and then translated into Urdu (native language); the participants were given the preferred version. Both the versions were reviewed by an expert in the field of waste management before data collection and were checked for correspondence. The questionnaire was validated by distributing it to different subject specialists.

EpiData Entry Client was used for data entry and Statistical Package of Social Sciences (SPSS-21) was utilized for data analysis. Descriptive Statistics are presented for each variable. Quantitative variables such as age are presented as mean \pm S.D. Qualitative variables such as profession are tabulated as frequency and percentages. Chisquare is applied to compare the responses of two groups i.e. doctors and nurses.

\section{RESULTS}

\section{Demographics}

Table-I mentions demographic characteristics of the study participants. One hundred and twenty three health-care workers took part in the study. Almost $50 \%$ were doctors and the rest were nurses. Most of the participants were working in major wards of surgery, medicine and gynecology.
ENT: Ear, Nose, Throat.

MBBS: Bachelor of Medicine, Bachelor of Surgery FCPS: Fellow of College of Physicians and Surgeons MCPS: Member of College of Physicians and Surgeons BS: Bachelors

BSN: Bachelors of Nursing

PG: Post graduate student

\begin{tabular}{|c|c|}
\hline Occupation & \\
\hline Doctors & 62 (50.4\%) \\
\hline Nurses & $61(49.6 \%)$ \\
\hline Age & $\begin{array}{c}\text { Mean } 24.98 \pm 4.04 \\
\text { Median } 24.00 \\
\text { Mode } 25\end{array}$ \\
\hline $\begin{array}{l}\text { Gender } \\
\text { Female } \\
\text { Male }\end{array}$ & $\begin{array}{l}98(79.7 \%) \\
27(20.3 \%)\end{array}$ \\
\hline \multicolumn{2}{|l|}{ Qualification } \\
\hline MBBS & $48(39.0 \%)$ \\
\hline FCPS-1 & $8(6.5 \%)$ \\
\hline FCPS/MCPS/MD & $6(4.8 \%)$ \\
\hline BS nursing & $28(22.8 \%)$ \\
\hline Diploma nursing & $9(7.3 \%)$ \\
\hline BSN students & 22 (17.9\%) \\
\hline PG nursing & $2(1.6 \%)$ \\
\hline $\begin{array}{l}\text { Experience } \\
\text { (In months) }\end{array}$ & $\begin{array}{c}\text { Mean } 45.50 \\
\text { Median } 24.00 \\
\text { Mode } 12 \\
\text { Standard deviation } 57.813\end{array}$ \\
\hline \multicolumn{2}{|l|}{ Department } \\
\hline Surgery & $40(32.5 \%)$ \\
\hline Medicine & $29(23.6 \%)$ \\
\hline Gynecology & $22(17.9 \%)$ \\
\hline Ophthalmology & $14(11.4 \%)$ \\
\hline $\begin{array}{l}\text { Others } \\
\text { Pathology } \\
\text { Radiology } \\
\text { Cardiology } \\
\text { Emergency } \\
\text { ENT }\end{array}$ & $\begin{array}{l}5(4.1 \%) \\
4(3.3 \%) \\
4(3.3 \%) \\
4(3.3 \%) \\
1(0.8 \%)\end{array}$ \\
\hline
\end{tabular}

Table-I. Demographic characteristics of participants

\section{Knowledge}

Most of the participants were aware about biomedical waste, considered it hazardous and knew related colour coding used for waste segregation. A significantly lower number of doctors were able to correctly identify the container for bio hazardous waste $(p=0.016)$. While majority (110 out of 123) of respondents 
correctly identified the containers for sharps and general wastes and no statistically significant difference was found between the responses of two groups $(p=0.352$ and 0.280$)$. Only $3(5.4 \%)$ of the nurses managed to spot the symbol for bio-hazardous waste and a significantly larger number of doctors correctly identified the symbol $(p=0.00)$. Overall, the knowledge about symbol was lacking in the respondents.

Most of the nurses had training on waste segregation while only a few doctors responded that they have been trained in waste segregation. Majority of nurses acknowledged that guidelines regarding waste segregation were available in their departments, whereas significantly fewer number of doctors acknowledged $(p=0.00)$ the existence of these guidelines at their workplace.
Twenty one percent of the respondents have had acquired infection from waste with no significant difference between the two groups.

A few of the questions in the questionnaire concerned both the attitude and practices of waste segregation in the hospital, hence the two categories have been grouped together. The views of the respondents differed when it came to their attitude and practices of waste segregation in their departments. Although, most of the respondents agreed that the practices were satisfactory and the equipment was available, there was a significant difference between the responses of doctors and nurses with the nurses being more satisfied with the available facilities and equipment $(p=0.00)$ than the doctors.

\begin{tabular}{|c|c|c|c|c|c|}
\hline Question & $\begin{array}{l}\text { Doctors } \\
\text { Number (\%of total who } \\
\text { responded to that question) }\end{array}$ & Nurse & Total & $\begin{array}{l}\text { Chi } \\
\text { square }\end{array}$ & P-Value \\
\hline Know about biomedical waste & $60(96.8 \%)$ & $61(100 \%)$ & $121(98.4 \%)$ & 2.00 & 0.157 \\
\hline $\begin{array}{l}\text { Consider health care waste } \\
\text { hazardous }\end{array}$ & $60(98.4 \%)$ & $61(100 \%)$ & $121(99.2 \%)$ & 1.008 & 0.500 \\
\hline $\begin{array}{l}\text { Know the color coding used for } \\
\text { segregation of hazardous and } \\
\text { non-hazardous waste }\end{array}$ & $52(88.1 \%)$ & $61(100 \%)$ & $113(94.2 \%)$ & 7.686 & 0.021 \\
\hline $\begin{array}{l}\text { Correctly identified the container } \\
\text { used for bio hazardous waste }\end{array}$ & $40(66.7 \%)$ & $50(82.0 \%)$ & $90(74.4 \%)$ & 8.270 & 0.016 \\
\hline $\begin{array}{l}\text { Correctly identified the container } \\
\text { used for sharps and needles }\end{array}$ & $53(85.5 \%)$ & $57(93.4 \%)$ & $110(89.4 \%)$ & 2.090 & 0.352 \\
\hline $\begin{array}{l}\text { Correctly identified the container } \\
\text { used for general waste }\end{array}$ & $56(93.3 \%)$ & $54(90.0 \%)$ & $110(91.7 \%)$ & 2.548 & 0.280 \\
\hline $\begin{array}{l}\text { Correctly recognized the symbol } \\
\text { for bio hazardous waste }\end{array}$ & $24(41.4 \%)$ & $3(5.4 \%)$ & $27(23.7 \%)$ & 41.847 & 0.000 \\
\hline $\begin{array}{l}\text { Ever had training on waste } \\
\text { segregation }\end{array}$ & $10(16.4 \%)$ & $44(72.1 \%)$ & $54(44.3 \%)$ & 49.137 & 0.000 \\
\hline $\begin{array}{l}\text { guidelines are available in the } \\
\text { department regarding medical } \\
\text { waste management }\end{array}$ & $40(64.5 \%)$ & $57(95.0 \%)$ & $97(79.5 \%)$ & 17.692 & 0.000 \\
\hline $\begin{array}{l}\text { acquired any infection from } \\
\text { hospital wastes or other materials }\end{array}$ & $13(21.3 \%)$ & $13(21.3 \%)$ & $13(21.3 \%)$ & 4.827 & 0.185 \\
\hline
\end{tabular}




\begin{tabular}{|c|c|c|c|c|c|c|c|}
\hline Statement & & $\begin{array}{l}\text { Strongly } \\
\text { Disagree }\end{array}$ & Disagree & Agree & $\begin{array}{l}\text { Strongly } \\
\text { Agree }\end{array}$ & $\begin{array}{l}\text { Chi- } \\
\text { square }\end{array}$ & P-Value \\
\hline $\begin{array}{l}\text { Are the waste management } \\
\text { guidelines by the Govt. } \\
\text { being followed in your } \\
\text { Hospital }\end{array}$ & $\begin{array}{l}\text { Doctors } \\
\text { Nurses } \\
\text { Total }\end{array}$ & $\begin{array}{l}2(3.3 \%) \\
0(0.0 \%) \\
2(1.6 \%)\end{array}$ & $\begin{array}{c}10(16.4 \%) \\
1(1.6 \%) \\
11(9.0 \%)\end{array}$ & $\begin{array}{l}46(75.4 \%) \\
40(65.6 \%) \\
86(70.5 \%)\end{array}$ & $\begin{array}{c}3(4.9 \%) \\
20(32.8 \%) \\
23(18.9 \%)\end{array}$ & 22.347 & 0.000 \\
\hline $\begin{array}{l}\text { Do you agree that correct } \\
\text { plastic bags and boxes are } \\
\text { available in your Hospital }\end{array}$ & $\begin{array}{l}\text { Doctors } \\
\text { Nurses } \\
\text { Total }\end{array}$ & $\begin{array}{l}4(6.5 \%) \\
0(0.0 \%) \\
4(3.3 \%)\end{array}$ & $\begin{array}{l}7(11.3 \%) \\
0(0.0 \%) \\
7(5.7 \%)\end{array}$ & $\begin{array}{l}43(69.4 \%) \\
34(55.7 \%) \\
77(62.6 \%)\end{array}$ & $\begin{array}{l}8(12.9 \%) \\
27(44.3 \%) \\
35(28.5 \%)\end{array}$ & 22.360 & 0.000 \\
\hline $\begin{array}{l}\text { Do you think that the waste } \\
\text { disposal practice are } \\
\text { satisfactory in your hospital }\end{array}$ & $\begin{array}{l}\text { Doctors } \\
\text { Nurses } \\
\text { Total }\end{array}$ & $\begin{array}{c}4(6.5 \%) \\
1(20.0 \%) \\
5(4.1 \%)\end{array}$ & $\begin{array}{c}18(29.0 \%) \\
1(1.6 \%) \\
19(15.4 \%)\end{array}$ & $\begin{array}{l}38(61.3 \%) \\
43(70.5 \%) \\
81(65.9 \%)\end{array}$ & $\begin{array}{c}2(3.2 \%) \\
16(26.2 \%) \\
18(14.6 \%)\end{array}$ & 28.202 & 0.000 \\
\hline $\begin{array}{l}\text { Do you always throw the } \\
\text { waste in the correct bin/ } \\
\text { container }\end{array}$ & $\begin{array}{l}\text { Doctors } \\
\text { Nurses } \\
\text { Total }\end{array}$ & $\begin{array}{l}3(4.8 \%) \\
0(0.0 \%) \\
3(2.4 \%)\end{array}$ & $\begin{array}{c}15(24.2 \%) \\
3(4.9 \%) \\
18(14.6 \%)\end{array}$ & $\begin{array}{l}38(61.3 \%) \\
36(59.0 \%) \\
74(60.2 \%)\end{array}$ & $\begin{array}{c}6(9.7 \%) \\
22(36.1 \%) \\
28(22.8 \%)\end{array}$ & 20.190 & 0.000 \\
\hline $\begin{array}{l}\text { Do you always wear } \\
\text { personal protective } \\
\text { equipment while handling } \\
\text { waste }\end{array}$ & $\begin{array}{l}\text { Doctors } \\
\text { Nurses } \\
\text { Total }\end{array}$ & $\begin{array}{l}8(13.3 \%) \\
1(1.7 \%) \\
9(7.6 \%)\end{array}$ & $\begin{array}{l}22(36.7 \%) \\
3(5.1 \%) \\
25(21.0 \%)\end{array}$ & $\begin{array}{l}25(41.7 \%) \\
27(45.8 \%) \\
52(43.7 \%)\end{array}$ & $\begin{array}{c}5(8.3 \%) \\
28(47.5 \%) \\
33(27.7 \%)\end{array}$ & 35.986 & 0.000 \\
\hline
\end{tabular}

Table-II. Attitude and practices of participants regarding health care waste segregation

\section{DISCUSSION}

Our study has demonstrated a better level of knowledge in the nurses regarding medical waste segregation as compared to doctors. Furthermore, the practices of waste segregation are also among nurses as reported by the respondents themselves. Overall the knowledge and practices of doctors are good, but they are deficient in waste segregation training and only $66.7 \%$ were able to correctly identify the container for biohazardous waste which is far from an ideal situation.

Studies in different regions of the world have demonstrated better knowledge of waste segregation among doctors and nurses. In a study targeting a tertiary level institute in India more doctors $(30 \%)$ were shown to have superior knowledge $(\geq 70 \%)$ and better attitude regarding medical waste segregation than nurses $(20 \%) .{ }^{12}$ A similar study at Alexandria Ambulatory Clinics revealed that none of the studied subjects received training in health-care waste management yet all of them were knowledgeable regarding the colour coding used for segregation of waste. ${ }^{17} \mathrm{~A}$ crosssectional study targeting students and faculty of dental colleges in Kothamangalam demonstrated that although the attitude regarding waste management was good, the knowledge and practices remained less than satisfactory ${ }^{18}$ Other studies have also concluded that doctors and nurses have superior practices and knowledge when compared with other healthcare staff. ${ }^{19,20}$

A comparison of waste management protocols in private and public sector hospitals in Shimla, India, revealed that private hospitals had manifested better results when it came to segregation of waste as per to the guidelines, even though only $7 \%$ had guidelines displayed at their facilities. ${ }^{21}$

A cross-sectional study in Lahore analysed the situation of medical waste management in five of the major hospitals of Lahore; Children Hospital, Shaukat Khanum Hospital, Sheikh Zayed Hospital, Mian Munshi Hospital and Shalamar Hospital of Lahore in July 2010 found waste segregation in various coloured containers/ bags like red, yellow and black was being practiced in $80 \%$ of the hospitals and needle cutter was available in $60 \%$ hospitals. ${ }^{22}$ A quasiexperimental study was conducted in different tertiary level government hospitals of Rawalpindi by interviewing $275 \mathrm{HCWs}$ including paramedics, sanitary workers, doctors and nurses during the preliminary survey described waste management 
practices followed with in the hospitals not to be significant $(p=0.33) .{ }^{23}$ However, in this study the sociodemographic characters like age, level of education, gender and experience were found to influence the practices, with $p<0.05$. Doctors and nurses had better knowledge, healthy attitude and superior practices regarding infectious waste management compared to paramedics and sanitary workers and was calculated to be statistically significant $(p<0.05) .{ }^{23}$ Another study observed the practices being followed in large private and public sector hospitals in Rawalpindi and Islamabad and reported that the practices were not up to the standards of $\mathrm{WHO}$ and Pakistan Biosafety rules $2005 .^{24}$

In the studies attempting to find the solution to the issue of medical waste management emphasis has been made on training of staff on waste segregation. National Health Service in Cornwall, United Kingdom recommended training the staff and enhancing awareness as the basis of several of the strategies advised for reducing the amount of waste produced and recover its value. According to NHS, such steps can reduce the hospital waste quantities by about $20-30 \%$ (of the wt.) and costs of its management up to $25-35 \% .{ }^{25}$ A short communication proclaiming an index of 87 research articles related to health-care waste management practices and problems in 40 low and middle income countries in the world suggested that the most recurrently observed reason was that health-care workers were uninformed, undertrained, and did not have adequate access to biomedical waste segregation systems. ${ }^{26} \mathrm{~A}$ study evaluating the risk of biomedical waste using a failure model advocated that in the packaging phase, the highest risk was posed by the 'sharp articles not placed in solid containers' mainly due to its high severity. ${ }^{27} \mathrm{~A}$ study by Oroei $\mathrm{M}$ also states similar opinions. ${ }^{28}$

\section{CONCLUSION}

The results of our study and other related studies makes it evident that though the knowledge and practices of healthcare workers nonetheless there is a lot of room for improvement vis a vis the efforts to reduce the hazards of biomedical waste and cost of its management. The evidence clearly points towards the dire need to improve quality of training of all healthcare staff as it is the most effective measure in improving waste management situation in hospitals.

Copyright $(26$ Feb, 2020.

\section{REFERENCES}

1. Kapoor D, Nirola A, Kapoor V, Gambhir RS. Knowledge and awareness regarding biomedical waste management in dental teaching institutions in India-A systematic review. Journal of clinical and experimental dentistry. 2014 Oct; 6(4):e419.

2. Health-care waste [Internet]. Who.int. 2019 [cited 11 May 2019]. Available from: http://www.who.int/ mediacentre/factsheets/fs253/en/.

3. Prüss-Üstün A, Townend WK. Safe management of wastes from health-care activities. World Health Organization; 1999.

4. Mol MP, Cairncross S, Greco DB, Heller L. Is waste collection associated with hepatitis B infection? A meta-analysis. Revista da Sociedade Brasileira de Medicina Tropical. 2017 Dec; 50(6):756-63.

5. World Health Organization. Safe management of wastes from health-care activities, 2nd ed. Geneva: World Health Organiation; 2014.

6. Pruss A, Giroult E, Rushbrook P. Safe management of wastes from health-care activities. World Health Organization. Geneva: Switzerland, 1999.

7. Minoglou M, Gerassimidou S, Komilis D. Healthcare waste generation worldwide and its dependence on socio-economic and environmental factors. Sustainability. 2017; 9(12):220.

8. Komilis D, Fouki A, Papadopoulos D. Hazardous medical waste generation rates of different categories of health-care facilities. Waste Management. 2012; 32(7):1434-1441.

9. Hossain MS, Santhanam A, Norulaini NN, Omar AM. Clinical solid waste management practices and its impact on human health and environment-A review. Waste management. 2011 Apr 1; 31(4):754-66.

10. Ranu R, Santosh K, Manju L. Knowledge, attitude and practice regarding biomedical waste management amongst health care personnel in a Medical College Hospital in Trivandrum. Ntl J Community Med 2016; $7(6): 457-460$. 
11. Kumar R, Khan EA, Ahmed J, Khan Z, Magan m, nousheen. Healthcare Waste Mmanagement (HCWM) in Pakistan: Current Situation and Training Options. J Ayub Med Coll. Abbottabad. 2010; 22(4).

12. Sachan R, Patel ML, Nischal A. Assessment of the knowledge, attitude and practices regarding biomedical waste management amongst the medical and paramedical staff in tertiary health care centre. International Journal of Scientific and Research Publications. 2012 Jul;2(7):1-6.

13. Health-care waste [Internet]. Who.int. 2019 [cited 11 May 2019]. Available from: https://www.who.int/newsroom/fact-sheets/detail/health-care-waste.

14. Ministry of Environment, Government of Pakistan. Hospital Waste Management Rules 2005. Islamabad: Ministry of Environment; 2005.

15. Punjab Health Department. Punjab Health Sector Reforms Programme (PHSRP) [Internet]. Phsrp. punjab.gov.pk. 2019 [cited 11 May 2019]. Available from: http://www.phsrp.punjab.gov.pk/phsrp.asp.

16. Kumar R, Samrongthong R, Shaikh BT. Knowledge, attitude and practices of health staff regarding infectious waste handling of tertiary care health facilities at metropolitan city of Pakistan. J Ayub Med Coll. Abbottabad. 2013; 25(1-2):109-12.

17. Soliman SM, Mostafa MA, Ibrahim HZ. Medical waste management situation at alexandria ambulatory Clinics. IOSR Journal of Nursing and Health Science. 2016; 05(05):01-09.

18. Sanjeev R, Kuruvilla S, Subramaniam R, Prashant PS, Gopalakrishnan M. Knowledge, attitude, and practices about biomedical waste management among dental healthcare personnel in dental colleges in Kothamangalam: A cross-sectional study. Health Sci. 2014; 1(3):1-2.

19. Ranu R, Santosh K, Manju L. Knowledge, attitude and practice regarding biomedical waste management amongst health care personnel in a Medical College Hospital in Trivandrum. Ntl J Community Med. 2016; 7(6):457-60.
20. Haifete $A N$, Justus $A H$, lita $H$. Knowledge, attitude and practice of health care workers on waste segregation at two public training hospitals. Eur J Pharm Med Res. 2016; 3(5):674-89.

21. Kumar S, Mazta SR, Gupta AK. Comparing the biomedical waste management practices in major public and private sector hospitals of Shimla City. International Journal of Scientific Study. 2015 Feb 1; 2(11):112-8.

22. Arshad N, Nayyar S, Amin F, Mahmood KT. Hospital waste disposal: A review article. Journal of Pharmaceutical Sciences and Research. 2011 Aug 1; 3(8):1412.

23. Kumar R, Samrongthong R, Shaikh BT. Knowledge, attitude and practices of health staff regarding infectious waste handling of tertiary care health facilities at metropolitan city of Pakistan. Journal of Ayub Medical College Abbottabad. 2013 Jun 1; 25(12):109-12.

24. Kumar R, Khan EA, Ahmed J, Khan Z, Magan M, Nousheen N, Mughal MI. Healthcare waste management (HCWM) in Pakistan: current situation and training options. Journal of Ayub Medical College Abbottabad. 2010 Dec 1; 22(4):101-6.

25. Tudor TL, Noonan CL, Jenkin LE. Healthcare waste management: A case study from the National Health Service in Cornwall, United Kingdom. Waste management. 2005 Jan 1; 25(6):606-15.

26. Harhay MO, Halpern SD, Harhay JS, Olliaro PL. Health care waste management: A neglected and growing public health problem worldwide. Tropical Medicine \& International Health. 2009 Nov; 14(11):1414-7.

27. Chen YC, Tsai PY. Evaluating the operational risks of biomedical waste using failure mode and effects analysis. Waste Management \& Research. 2017 Jun; 35(6):593-601.

28. Oroei M, Momeni M, Palenik CJ, Danaei M, Askarian M. A qualitative study of the causes of improper segregation of infectious waste at Nemazee Hospital, Shiraz, Iran. Journal of infection and public health. 2014 May $1 ; 7(3): 192-8$. 


\section{AUTHORSHIP AND CONTRIBUTION DECLARATION}

\begin{tabular}{|c|c|c|c|}
\hline Sr. \# & Author(s) Full Name & Contribution to the paper & Author(s) Signature \\
\hline 1 & Saleha Qasim & $\begin{array}{l}\text { Study design, Queionnaire making, Data } \\
\text { collection, Data entry, Analysis, Writing of the }\end{array}$ & Setallaw \\
\hline 2 & Ainul Momina & $\begin{array}{l}\text { research article, Revision. } \\
\text { Study design, Analysis, Writing of the } \\
\text { research article, Reivsion. }\end{array}$ & \\
\hline 3 & Fatima Tul Zahra & $\begin{array}{l}\text { Study design, Data collection, Data entry, } \\
\text { Analysis, Writing of the research article. }\end{array}$ & \\
\hline 4 & Tahira Bano Qasim & $\begin{array}{l}\text { Study design, Questionnaire making, } \\
\text { Analysis, Writing of the research article, }\end{array}$ & fow \\
\hline 5 & Fakeha Rehman & $\begin{array}{l}\text { Revision. } \\
\text { Study design, Analysis, Writing of the } \\
\text { research article, Revision. }\end{array}$ & $\frac{1}{a}$ \\
\hline
\end{tabular}

